\title{
Histological and histomorphometric evaluation of the retina of mice infected with Schistosoma mansoni in its hepatosplenic form ${ }^{1}$
}

\author{
Avaliação histológica e histomorfométrica da retina de camundongos infectados pelo \\ Schistosoma mansoni na forma hepatoesplênica
} \author{
Azevedo Albuquerque ${ }^{\mathrm{IV}}$ \\ ${ }^{\text {I }}$ Master of Science in Surgery, UFPE, Pernambuco, Brazil.
${ }^{\text {II }} \mathrm{PhD}$, Full Professor, Head Division of Pediatric Surgery, UFPE, Pernambuco, Brazil.
${ }^{\text {III }} \mathrm{PhD}$, Full Professor, Head Division of Pathology, UFPE, Pernambuco, Brazil.
${ }^{\text {IV }} \mathrm{PhD}$, Associate Professor, Tropical Medicine Department, UFPE, Pernambuco, Brazil.
}

Maria Cecília de Aguiar Remígio ${ }^{\mathrm{I}}$, Carlos Teixeira Brandt ${ }^{\mathrm{II}}$, Nicodemos Teles de Pontes Filho ${ }^{\mathrm{III}}$, Monica Camelo Pessoa de

\begin{abstract}
Purpose: To evaluate retinal manifestations of Schistosomiasis mansoni in its hepatosplenic form in mice. Methods: It was performed a study with two groups of mice; one of them was infected with 40 cercariae of Schistosoma mansoni. After 120 days of the infection, the eyes underwent a retinal microscopy study. The histology findings were reported. Histomorphometric analysis was also performed, including: thickness measurement of the retinal layer and the number of the ganglion layer cells. Results: In one case a retinal granuloma was found. The analysis of the other histological sections demonstrated normal architecture of the retina. The mean thickness of the retinal layer between the two groups were similar $(41.81 \pm 6.09 \mu \mathrm{m}$ versus $38.48 \pm 8.58 \mu \mathrm{m}-\mathrm{p}=0.279)$; as well as the mean number of the ganglion layer cells $(20.93 \pm 4.88$ versus $20.64 \pm 4.10-\mathrm{p}=0.864)$. Disorganization of the retinal layers was not identified and the histomorphometric analysis revealed no significant difference between the two groups. Conclusion: The absence of findings in this study does not exclude that hemodynamic and autoregulation changes associated with hepatosplenic schistosomiasis could be correlated to retinal manifestations. It is necessary that other methods with a high parasite infection should be performed.
\end{abstract}

Key words: Schistosomiasis mansoni. Retina. Histology. Mice.

\section{RESUMO}

Objetivo: Avaliar as repercussões da esquistossomose mansônica na forma hepatoesplênica na retina de camundongos. Métodos: Foi realizado estudo com dois grupos de camundongos, sendo um infectado com 40 cercárias do Schistosoma mansoni. Decorridos 120 dias da infecção, os olhos foram submetidos à análise microscópica da retina com descrição dos achados histológicos e realizada análise histomorfométrica com mensuração da espessura de segmento retiniano e do número de células da camada ganglionar. Resultados: Em um caso foi encontrado um granuloma retiniano. Já a análise dos demais cortes histológicos demonstrou uma arquitetura normal da retina. A média da espessura dos segmentos retinianos entre os grupos de camundongos, controle e infectado, foi similar $(41,81 \pm 6,09 \mu \mathrm{m}$ versus $38,48 \pm 8,58 \mu \mathrm{m}-\mathrm{p}=0,279)$ assim como a média do número de células da camada ganglionar $(20,93 \pm 4,88$ versus 20,64 $\pm 4,10-p=0,864)$. A estrutura da retina encontrava-se íntegra e a análise histomorfométrica não revelava diferença significante entre os dois grupos. Conclusão: A ausência de alterações, neste estudo, não afasta a possibilidade de que desequilíbrios hemodinâmicos e no mecanismo de autoregulação, em portadores da forma hepatoesplênica da esquistossomose, possam acarretar dano retiniano. Demanda, entretanto, que outras metodologias com indução da infecção com uma maior carga parasitária sejam realizadas.

Descritores: Esquistossomose mansoni. Retina. Histologia. Camundongos.

${ }^{1}$ Research performed at Department of Surgery and Laboratory of Immunology and Pathology Keizo Asami (LIKA), Federal University of Pernambuco (UFPE), Brazil.

\section{Introduction}

Schistosomiasis is considered a major public health problem, which affects more than 200 million individuals distributed in 76 countries in Africa, Asia or America. Among these, $10 \%$ present the hepatosplenic form of the disease, and 50 to
$60 \%$ of infected people present clinical manifestation, constituting a huge public health problem ${ }^{1,2}$.

When eggs, worms or antigen-antibody immunocomplex can be found outside the portal circulation, it is considered to be ectopic schistosomiasis ${ }^{3}$. Ocular lesions have been reported with an inflammatory response induced by $S$. mansoni eggs similar to 
those observed in the livers of infected hosts. Retinal manifestations, such as hemorrhages, granulomas, tortuosity and enlargement of the vessels were observed in association with the hepatosplenic form ${ }^{4-17}$. Damage to the retinal nerve fiber layer and the retard of retinal contrast arrival time in the angiofluoresceinographic exam were also reported due to ocular hemodynamic alterations $\mathrm{s}^{6,8,11}$.

Schistosoma mansoni is responsible for lesions that can alter the hemodynamic of the portal venous circulation and venous systemic system. A number of secondary phenomena occur with portal hypertension. The fundamental initiating factor is an increase in resistance to portal venous flow. Systemic vascular resistance and mean arterial blood pressure fall and both cardiac vascular output and blood flow increase. Current theories suggest that increased vascular production of nitric oxide may also have a role in the pathogenesis of these processes ${ }^{18-22}$. Therefore, hemodynamic changes in the ocular circulation of mansonic schistosomotic patients with portal hypertension probable can cause secondary ischemia of the retina and damage to the their layers.

The purpose of this study was to report the retinal histology findings and perform histomorphometric analysis, thickness measurement of the retinal layer and the number of the ganglion layer cells, in mice infected with the hepatosplenic form of the Schistosoma mansoni.

\section{Methods}

Thirty-five healthy female Swiss mice, weighing around 20-25g were divided into two experimental groups: control $(n=10)$ and infected $(n=25)$. Each mouse of the second group was infected by exposing their tails to a suspension of 40 cercariae of the Belo Horizonte strain of Schistosoma mansoni for two hours at a temperature of $28^{\circ} \mathrm{C}$. The study has been approved by the local research ethics committee.

They were kept under environmentally-controlled conditions in a well ventilated room with free access to water and to a balanced commercial diet for mice. During this time happened the death of three infected mice.

After 120 days of the exposure to cercariae, all animals were sacrificed by cervical fracture and the mice of the second group were also submitted to parasitological diagnosis, Kato-Katz's method, and to the perfusion technique to recovery the worms from the hepatic and portomesenteric veins.

The livers, spleens and eyes were taken and carefully fixed in $10 \%$ formalin and submitted to paraffin sections stained with hematoxilin-eosin. They were all subjected to histopathologic findings and the eyes also underwent the procedure for histomorphometric analysis.

It was obtained five horizontal sections of each eye, alternating at $10 \mu \mathrm{m}$, including the peripapillary area. Four images of each section were acquired under 400x magnification and histomorphometric analyses were performed with the software Image J 9.1. The parameters measured were: thickness measurement of the retinal layer segment and the number of the ganglion layer cells. Four measures were performed of each image and calculated their average for subsequent statistical analysis. For each animal was performed an average of these measures (Figures 1 and 2).

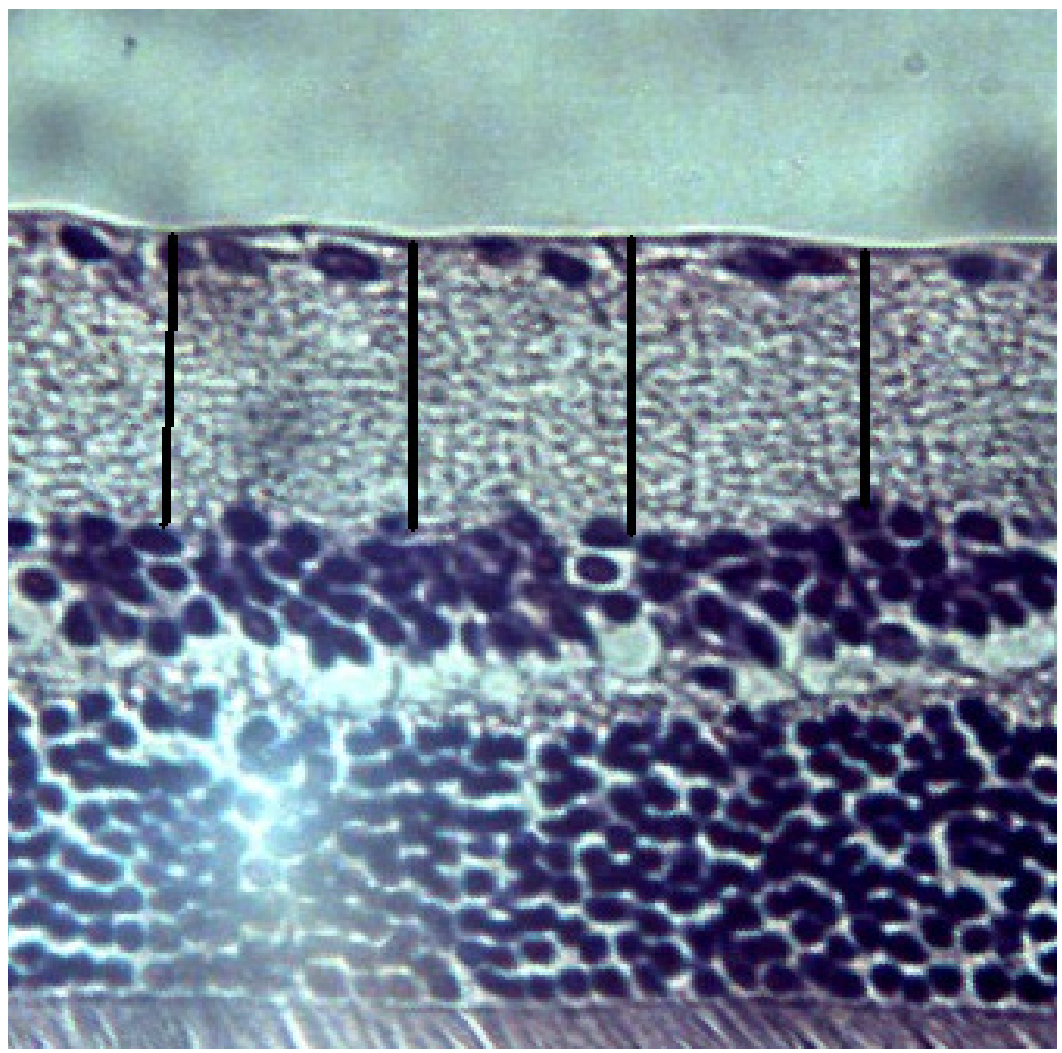

FIGURE 1 - Measurement of the retinal layer 


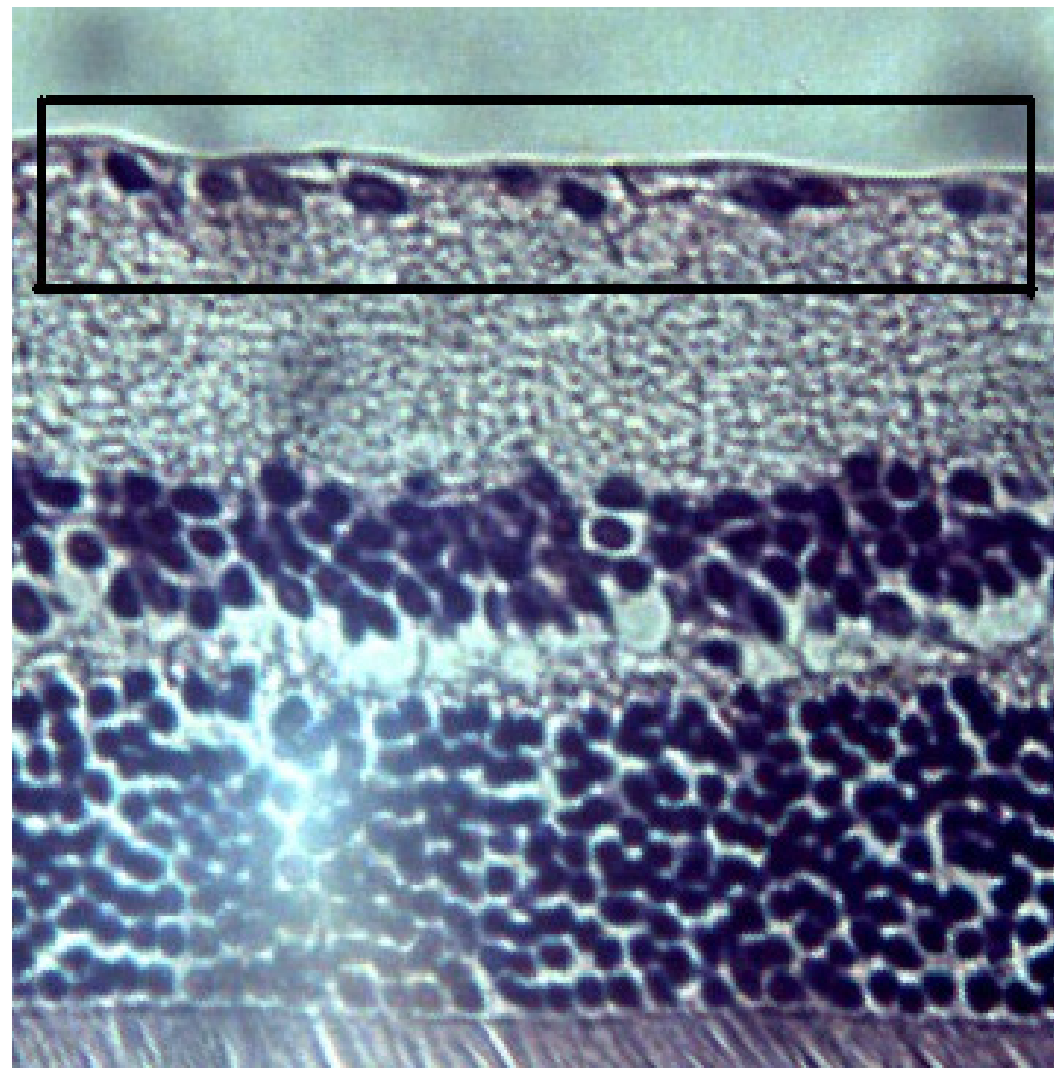

FIGURE 2 - Measurement of the number of the ganglion layer cells.
The data were further analyzed using " $t$ " Student test to verify the difference between means for non-related samples and Levene's test to verify if samples have equal variances. Differences were deemed statistically significant when $p$ values were lower than 0.05 .

\section{Results}

All animals exposed became infected, and this was perceived by the presence of numerous parasite eggs in the sections examined and the number of worms recovered. They presented changes in the liver and spleen that confirmed the disease.

The histopathological findings of the eyes sections from the second group did not demonstrate structural changes or inflammatory cells in the retinal layers. However in one eye of an animal of this group it was revealed a presence of one periovular retinal granuloma surrounded by lymphocytes, plasmocytes and histiocytes cells (Figure 3 ).

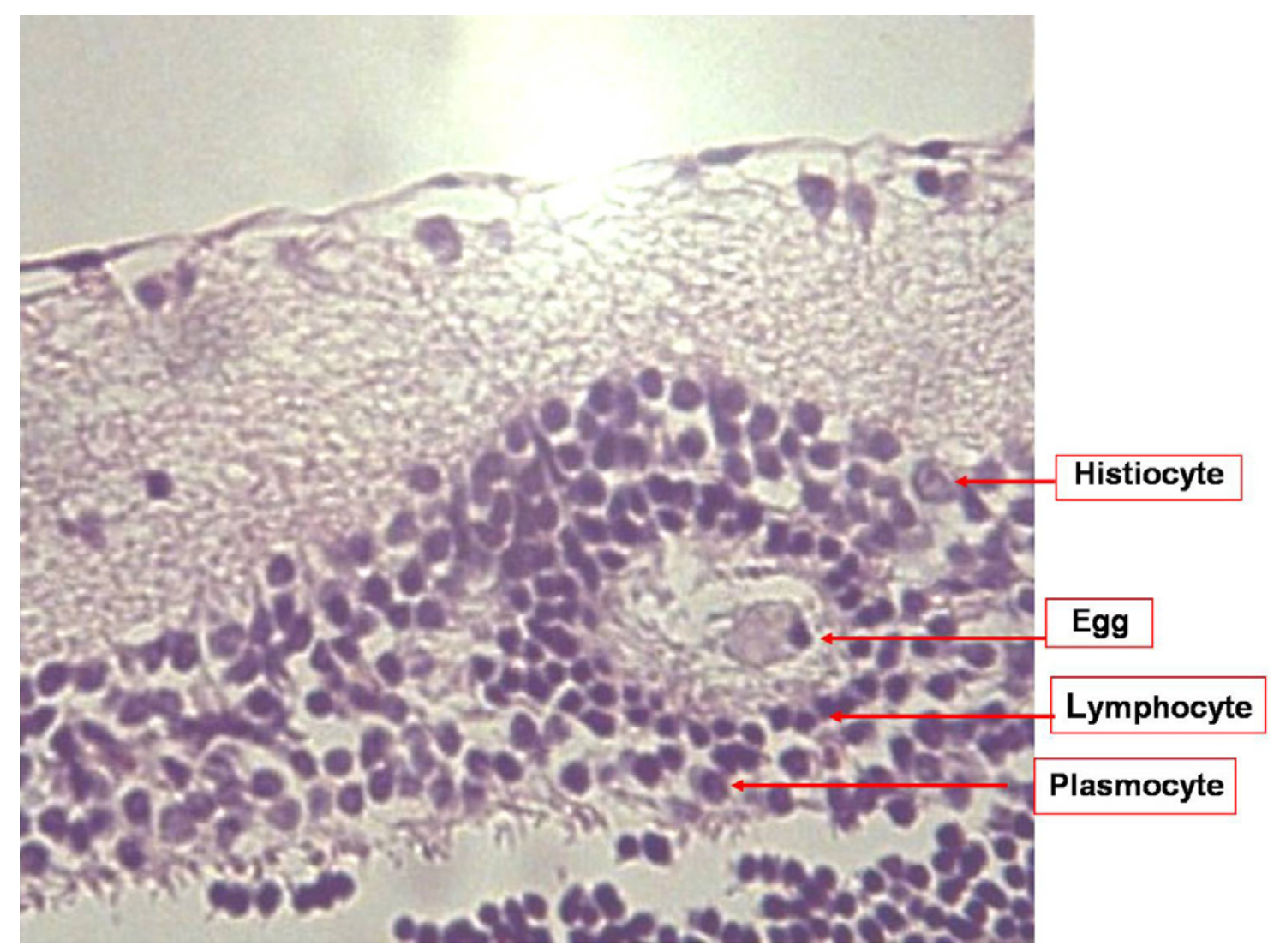

FIGURE 3 - Retinal periovular granuloma (HE 400X) 
The Table 1 shows the statistical values of the thickness measurement of the retinal layer and the Table 2 shows the statistical values of the number of the ganglion layer cells of both groups. There was not a statistically significant between the groups $(\mathrm{p}>0.05)$.

TABLE 1 - Statistical values of the thicknes measurement of the retinal layer of both groups

\begin{tabular}{lccc}
\hline Statisticals & \multicolumn{3}{c}{ Group } \\
& $(\mathrm{n}=10)$ & $\begin{array}{c}\text { Infected } \\
(\mathrm{n}=22)\end{array}$ & p value \\
\hline Mean $^{(2)}$ & & & $\mathrm{p}^{(1)}=0.279$ \\
Median $^{(2)}$ & 41.81 & 38.48 & \\
Standard deviation $^{(2)}$ & 41.82 & 37.84 & \\
CV (\%) $^{(2)}$ & 6.09 & 8.58 & \\
Minimum $^{(2)}$ & 14.57 & 22.31 & \\
Maximum $^{(2)}$ & 30.01 & 20.48 & \\
& 52.23 & 64.47 & \\
\hline
\end{tabular}

(1): Through the Student t-test with equal variances

(2): Values in micrometer

$\mathrm{CV}$ : coefficient of variance

TABLE 2 - Statistical values of the number of the ganglion layer cells of both groups

\begin{tabular}{lccc}
\hline Statisticals & $\begin{array}{c}\text { Control } \\
(\mathrm{n}=10)\end{array}$ & $\begin{array}{c}\text { Group } \\
\text { Infected } \\
(\mathrm{n}=22)\end{array}$ & p value \\
\hline Mean $^{(2)}$ & 20.93 & 20.64 & $\mathrm{p}^{(1)}=0.864$ \\
Median $^{(2)}$ & 20.63 & 19.68 & \\
Standard deviation $^{(2)}$ & 4.88 & 4.10 & \\
CV (\%) & 23.31 & 19.86 & \\
Minimum $^{(2)}$ & 13.75 & 14.00 & \\
Maximum $^{(2)}$ & 29.75 & 32.00 & \\
& & & \\
\hline
\end{tabular}

(1): Through the Student t-test with equal variances

(2): Values in micrometer

$\mathrm{CV}$ : coefficient of variance

\section{Discussion}

It was observed a normal architecture of the retina and one retinal granuloma in the group of the infected animals.

The absence of results could be related to the method of the infection once the mice were exposed to a low number of cercarie to avoid the death of a great number of the sample. This may have caused no development of more severe systemic disease since it is already established the importance of the relation between the intensity of infection and severe form of disease in determining the hepatosplenic schistosomiasis.
The fact that the object of study was the peripapillary region may have influenced the lack of ocular findings, as already described in other studies ${ }^{4-17}$. It was not searched throughout the globe since the intention was to evaluate a particular segment of the eye.

The double staining with hematoxylin-eosin aims to contrast tissue structures, but does not provide information about their chemical nature. Perhaps using another method of histological processing, which allow a more detailed observation, retinal changes could be identified. 
In this study, the attempt to associate the histopathological parameters of the retina by histomorphometry, resulted in not significant data when comparing the groups. The absence of these findings may be the result of the proposed model which was based primarily on the development of systemic disease, and therefore, to find secondary ocular changes. The goal was to simulate the usual form of the development of the disease in contrast to other experimental studies, which the direct inoculation of parasites or eggs were performed ${ }^{4,7,14,16}$.

Another point to be considered is that the data were obtained from an intervention study in mice. Despite having already established its role as an important animal model in the development of schistosomiasis, there are intrinsic factors to each host that result in difference response given to the mechanism of infection $^{22}$. The possibility of generalization of results must be examined with considerable caution. Not all knowledge generated in animal models is fully transferable to humans.

Disorganization of the retinal layers was not identified and the histomorphometric analysis revealed no significant difference between the two groups

\section{Conclusion}

The absence of findings in this study does not exclude that hemodynamic and autoregulation changes associated with hepatosplenic schistosomiasis could be correlated to retinal manifestations. It is necessary that other methods with a high parasite infection should be performed.

\section{References}

1. OMS. Organización Mundial de la Salud. Prevención y controle de la esquistosomiasis y las geohelmintiasis: Informe de un comité de expertos de la OMS. 2005; Serie de informes técnicos, 912, Ginebra, Suiza.

2. Van Der Werf MJ, Vlas SJ, Brooker S, Looman CWN, Nagelkerke NJD, Habbema JDF, Engels D. Quantification of clinical morbidity associated with schistosome infection in sub-saharian Africa. Acta Tropica. 2003;86:125-39.

3. Oréfice F, Simal CJR, Pittella JEH. Schistosomotic Choroiditis I: fundoscopic changes and differential diagnosis. Br J Ophthalmol. 1985;69:294-9.

4. Queiroz JM. Aspectos experimentais e clínicos das manifestações oculares da esquistossomose mansoni. Oftalmol Iberoam. 1961;22(4):115-78. 5. Lemos E. Alterações retinianas na esquistossomose hepatoesplênica. Rev Bras Oftalmol. 1980;24:123-8.
6. Matos MAG, Brandt CT, Dantas H, Carmo CM. Camada de fibras nervosas da retina em portadores de esquistossomose hepatoesplênica: Análise com laser confocal polarizado. Anais da Faculdade de Medicina da Universidade Federal de Pernambuco. 2003;48(2):117-23.

7. Newton JC, Kanchanaranya C, Previte Jr. Intraocular Schistosoma mansoni. Am J Ophthalmol. 1968;65(5):774-8.

8. Souza ACD, Brandt CT, Ventura C. Hemodinâmica ocular em portadores da forma hepatoesplênica da esquistossomose mansônica: avaliação dopplerfluxométrica. Anais da Faculdade de Medicina do Centro de Ciências da Saúde da UFPE. 2005;50(1):45-50.

9. Pittella JEH, Oréfice F. Schistosomotic Choroiditis II: report of first case. Br J Ophthalmol. 1985;69:300-2.

10. Oréfice F, Pittella JEH, Simal CJR, Coscarelli G. Uveíte esquistossomótica: alterações fundoscópicas, achados histológicos do ovo do $S$. mansoni, abordagem da etiologia e tratamento. Arq Bras Oftalmol. 1988;51(3):123-34.

11. Souza ACD, Brandt CT, Ventura L, Oréfice F. Retinal fluorescein contrast arrival time of young patients with the hepatosplenic form of the Schistosomiasis mansoni. Mem Inst Oswaldo Cruz. 2002;97 (Suppl 1):161-4.

12. Randriamora JT, Rabarijaona HZ, Rabearivony N, Bernardin P, Rasoavelonoro VA. Bulbar subconjunctival tumor secondary to periocular schistosome granuloma. J Fr Ophtalmol. 2004;27(9 Pt 1):1043-5.

13. Bey MS. La bilharziose palpebro-conjuntivale. Ann Ocul. 1928; 165:675-84.

14. Goodchild CG. Implantation of Schistosoma douthitti into the eyes of rats. Exp Parasitol. 1958;7:152-64.

15. Abboud IA, Hanna LS, Ragab AA. Experimental ocular schistosomiasis. Br J Ophthalmol. 1971;55:106-15.

16. Lester RJG, Freeman RS. Eye penetration by cercariae of Schistosoma mansoni. J Parasitol. 1975;61(5):970-2.

17. Stein PC, Char DH. Intraocular granuloma: a Schistosoma mansoni model of ocular inflammation. Invest Ophthalmol Vis Sci. 1982;23:478-88. 18. Anderson DR. Glaucoma capillaries and pericytes: blood flow regulation. Ophthalmologica. 1996;210:257-62.

19. Cichoz-lach H, Celinski K, Slomka M, Kasztelan-szczerbinska B. Pathophysiology of portal hypertension. J Physiol Pharmacol. 2008;59(Suppl 2):231-8.

20. Shah V. Molecular mechanisms of increased intrahepatic resistance in portal hypertension. J Clin Gastroenterol. 2007;41(Suppl 3):S259-261.

21. Brandt CT, Leite CR, Manhaes-de-Castro FM, Macedo EM, Silva RP, Castro CM. Níveis de óxido nítrico produzidos por monócitos em portadores de esquistossomose hepatoesplênica que se submeteram a esplenectomia, ligadura da veia gástrica esquerda e auto-implante de tecido esplênico no omento maior. Acta Cir Bras. 2006;21(5):285-90.

22. Rocha MOC, Coelho PMZ, Rocha RL. O camundongo (Mus musculus) como modelo experimental na esquistossomose mansoni. Rev Med Minas Gerais. 1994;3:20-2.

\section{Correspondence:}

Conflict of interest: none

Maria Cecília de Aguiar Remígio

Rua Simão Mendes, 144/301

52050-110 Recife - PE Brazil

ceciliaremigio@uol.com.br

Received: May 27, 2009

Review: July 23, 2009

Accepted: August 25, 2009

\footnotetext{
How to cite this article

Remígio MCA, Brandt CT, Pontes-Filho NT, Albuquerque MCPA. Histological and histomorphometric evaluation of the retina of mice infected with Schistosoma mansoni in its hepatosplenic form. Acta Cir Bras. [serial on the Internet] 2009 Nov-Dez;24(6). Available from URL: http://www.scielo.br/acb
} 